\title{
Debating Hydrofracking: The Discursive Construction of Risk
}

\section{OPEN ACCESS}

Edited by:

Tracylee Clarke,

California State University, Channel

Islands, United States

Reviewed by:

Jen Schneider,

Boise State University, United States

Cristi Choat Horton,

Tarleton State University,

United States

${ }^{*}$ Correspondence: Richard Buttny

rbuttny@syr.edu

Specialty section:

This article was submitted to Science and Environmental

Communication,

a section of the journal

Frontiers in Communication

Received: 18 June 2018 Accepted: 28 January 2019 Published: 27 March 2019

Citation:

Buttny R (2019) Debating Hydrofracking: The Discursive Construction of Risk.

Front. Commun. 4:5

doi: 10.3389/fcomm.2019.00005

\section{Richard Buttny* \\ Department of Communication and Rhetorical Studies, Syracuse University, Syracuse, NY, United States}

This study examines a debate among experts sponsored by Cornell University in 2014 on whether or not to allow hydrofracking in New York State. The focus is on the question-answer portion of the debate to see how risk is discursively constructed from experts' claims and rejoinders as well as audience participation. The granular methodology of discursive analysis is used to examine how risk gets talked into being and amplified or mitigated through interaction in the question-answer portion of the debate. Risk gets constructed through participants' practices of metadiscourse-how they formulate what has been said, report the speech or actions of others, or repeat certain locutions into lists for rhetorical effect. These metadiscourse practices provide a resource for the debater to critically characterize other's words or deeds prior to presenting their preferred position.

Keywords: hydrofracking, risk, discursive analysis, environmental conflict, debate, experts

\section{INTRODUCTION}

Hydrofracking is a new technology that allows for access to previously untapped sources of natural gas or oil. Hydrofracking, a shorthand for "high-volume, horizontal hydraulic fracturing," or simply "fracking," involves injecting millions of gallons of water, chemicals, and sand into a wellhead at high pressure to fracture shale or a coal-seam formation to release gas or oil (Duggan-Hass et al., 2013). This emerging technology became able to drill more than a mile along with horizontal extensions to frack open the gas trapped in shale or coal seams. Hydrofracking has been seen in remarkably disparate ways, on the one hand, as a "game changer" for US energy production, job creation, and reduced fossil fuel emissions compared to coal, but on the other hand, as an environmental or public health hazard due to drinking water contamination, air pollution, methane emissions affecting climate change, or seismic activity. These competing perceptions led to a politicization of hydrofracking and a polarization between advocates and opponents (Christenson et al., 2017). The conflict over hydrofracking has played out in newspapers and television (Metze, 2014; Metze and Dodge, 2016), on industry and state web pages (Guignard, 2013; Chen and Gunster, 2016), during municipal or town meetings (Wilber, 2015; Kroepsch, 2016; Mando, 2016; Auyero et al., 2017), or during inter-governmental hearings (Buttny, 2015, 2017). The hydrofracking debate, however, has not been studied during an actual debate on hydrofracking. The present paper examines a debate on hydrofracking while the controversy was 
still raging in New York State during 2014. A face-to-face debate on hydrofracking offers an intriguing communication context for understanding hydrofracking discourse in that it brings together technical experts and leading advocates to articulate their positions, address opposing views, and answer audience questions.

\section{THE HYDROFRACKING DEBATE}

By the 2000s hydrofracking technology was capable of tapping into the Marcellus Shale, the richest natural gas play in the US, primarily under the states of Pennsylvania, Ohio, and New York. Pennsylvania, with its history of mineral extraction, readily allowed drilling to begin assuming that the industry would take care of itself. New York was also eager to benefit from the projected economic boon, but delayed permitting drilling until their environmental regulations could be updated for this new technology. Initially there was a "gas rush" fever among land owners in New York in anticipation of an economic windfall from leasing their land and royalties from drilling (Wilber, 2015). But environmental problems began to surface, for example, in Dimock, Pennsylvania when a homeowner's well-exploded from nearby hydrofracking. Also, neighbors' well-water became contaminated; spills of toxic flow-back fluids from containment areas were discovered along with the dumping of waste fluids into rivers. Community disruption occurred from the influx of outof-state workers along with numerous truck trips leading to the degrading of roads (Perry, 2012; Guignard, 2013).

Opposition to hydrofracking began as environmental impacts received more coverage in the press (Mazur, 2016). Grass-roots opposition groups arose (Briggle, 2015; Gullion, 2015; Wilber, 2015; Auyero et al., 2017) and were galvanized by the documentary film, Gasland (Vasi et al., 2015). Opposition focused on a number of issues: water contamination, industrialization of rural areas, air pollution, seismic activity, increased truck traffic and road damage, boom-bust economy, or social problems from man camps and out-of-state workers. Proponents of fracking focused on a revitalized economy for depressed rural areas and the creation of new jobs along with the patriotic message of energy independence (Rich, 2016). Hydrofracking may promote energy security and affordability, but it also discourages a transition to alternative energy sources (Pidgeon et al., 2017). One's position on hydrofracking may be based more on one's political identity with Democrats generally opposed and Republicans in favor (Dokshin, 2017). Even with all this controversy, a national poll found that a large number of people surveyed did not know or have an opinion about hydrofracking (Boudet et al., 2014).

In New York State Dodge's (2017) study of the hydrofracking controversy found different interests coalesced into competing "discourse coalitions" to advocate and respond to opponents. Initially a "gas rush coalition" formed among industry representatives, landowners, and political officials eager for economic development in the New York's Southern Tier. A "landowners' rights collation" formed to negotiate for better deals for landowners from the industry. At the same time, questions were being raised at town meetings about the safety of this new technology which led political officials and state agencies to update their regulations which created "an environmental regulation coalition." Given these questions about safety along with reports of environmental problems from other states led to the formation of "an environmental threat coalition" of grassroots citizen groups, environmental organizations, and political officials. Dodge (2017) examined how these competing discourse coalitions evolved as their knowledge grew and advocates responded to each other and new storylines developed over the course of the controversy from 2007 to 2014. These discourse coalitions' arguments and rhetoric emerged through their (i) framing of facts and scientific claims, (ii) framing self and other, and (iii) framing of various situations.

\section{RATIONALE AND PERSPECTIVE}

The hydrofracking controversy will be approached here from a social constructionist perspective on risk (Lupton, 2013). Risk involves real dangers in the world as well as how people socially construct risk (Krimsky and Plough, 1988). Urlich Beck theorizes that we have become a "risk society" (Beck, 1992). The advances brought about from industrialization also brought about unintended public health risks and environmental degradation. There are not necessarily more risks today than in the past though we are more aware of them. Trust in government and big corporations to protect ordinary people from the hazards of industrial development have declined in recent years (Douglas, 1992). To be "at risk" is a condition that needs to be articulated, spoken into being through various forms of communication. As Boholm (2009, p. 345) puts it, "Identifying something as a 'risk' involves symbolic processes of representation that, by means of categories, associations, distinctions, evaluations, and argumentation, establishes the 'risky' character of an object." Claims about the riskiness of a project occur in interaction with others (Myers, 2007). Opponents of a project typically amplify the risks, while proponents attenuate the risk (Renn, 1992). But this social amplification of risk framework relies on a problematic transmission model of communication (Pidgeon et al., 2006). Processes of amplification need to be seen in context, as part of ongoing social interaction. The approach of this study will be to see on how risk gets socially constructed, that is, what discursive practices are used and how these are evaluated and responded to by others.

The decision on whether or to permit hydrofracking was arguably the most contentious environmental policy dispute in New York State history. The controversy played out in several communication contexts: television and radio specials, industry advertisements, webpages, social media, documentary films, town meetings, public hearings, court cases on home rule, lawn signs, and in ordinary conversations. New York Governor Andrew Cuomo famously said that the State's decision on hydrofracking needs to be based on science, not politics (Kiernan, 2012). While science alone cannot settle the matter, the Governor's pronouncement underscored the importance of expert testimony for understanding the risks with hydrofracking. 
The present case study focuses on a debate among experts who argue for or against permitting hydrofracking. An expert is defined here as a person with a high level of competence in a disciplinary field that is typically certified by a professional peer group (Fisher, 2000, p. 280-281). The value of a public debate among experts is that proponents must not only articulate their position but also address opponents' views and counterarguments as well as answer audience questions.

This controversy has been ongoing for over 5 years, so that opposing sides have become polarized. This debate represents a classic case of competing experts on the risks with hydrofracking. The debate context makes for a kind of performative contest among experts. These experts face critical questions and need to have quick answers which may be rebutted by opponents. "Expertise is (the) ability to 'finesse reality and animate evidence through the mastery of verbal performance (Matoesian, 1999)"' (Carr, 2010, p. 23). Experts need to manage the audience and respond appropriately to challenges (Llewellyn, 2005). One shows one's expertise, not only by being fully credentialed in one's profession, but also by how one displays expertise in and through their discourse.

To study the social construction of risk in this debate a discourse analysis methodology will be used, more specifically, discursive constructionism (Buttny, 2004). The focus of this approach is on participants' discursive practices in constructing a version of events, i.e., an account. Discursive analysis attempts to reveal the interactive moves and positionings that participants take in making claims about hydrofracking (Buttny, 2015, 2017). The focus is not only on the content of participants' claims, but also on how these claims are interactively constructed and, in turn, evaluated by others, and how this plays out. Discursive analysis, as a close reading of a text, has certain affinities with rhetorical analysis (Tracy, 2003). But in addition to a close reading, discursive analysis also looks at the interaction to see how participants understand, evaluate, and respond to their interlocutor. Risk is discursively constructed in and through the interaction of the debate.

Given that the debate is before a live audience, how the audience enters into the debate also will be examined. The question-answer portion of the debate is analyzed for how the debaters formulate the question they are asked by the audience member. The debaters address or implicate the audience as well as their opponents in various ways. The audience participates, not only through their questions and claims, but also through applause, laughter, or heckling. During the debate, audience members' questions often contain challenges which implicate the expert's accounts. These question-answer sequences involve challenge-account interaction. They are fraught with differences, disagreements, or drama over the risks with hydrofracking (Palmlund, 1992; Hilgartner, 2000).

\section{METHODS AND DATA}

A video-recording was made of this debate by the Cornell Forensics Club (2014). I was unable to attend the debate due to a prior commitment. From the video recording I drew up a transcript of the debate which is used as the data for this study (see Appendix for symbols used in the transcription). The transcription captures, not only the words said, but also how those words are said as well as interactive dynamics such as overlapping speech or pauses or silences. Discursive analysis examines what participants are doing with their words and how they are taken and responded to by recipients. How the words are said (e.g., emphatically, slowly, softly) is important because it helps us understand the expressive aspects of those words, that is, how to take those words-as literal or ironic, with what degree of emotional intensity, or as implicating other meanings. Ways of being emphatic through vocalic loudness, stretching words, or repetition is noted for the construction of meaning. Also, represented are audience noises such as applause, laughter, heckling, or grumbling. The granular level of detail represented in the transcripts is important because this helps us to better understand what participants are saying and doing in their exchanges (Hepburn and Bolden, 2017).

Excerpts from the question-and-answer portion of the debate were selected for analysis. These excerpts include an audience member's question and different experts' competing accounts and conflicting assessments. The analysis attempts to uncover the discursive practices used in constructing competing accounts of risk.

An ethics approval was not required for this study as per institutional and national guidelines and regulations. Since this debate was a public event obtaining written informed consent from participants was not required as per the ethics committee of the author's institution.

\section{CONTEXT OF THE DEBATE}

Polls taken around the time of the debate (2014) showed that public opinion in New York State was largely divided on permitting hydrofracking with a slight majority opposed. There was a moratorium on hydrofracking while the Department of Environmental Conservation (DEC) was revising the environmental impact statement, officially called the Supplemental Generic Environmental Impact Statement (SGEIS). The DEC had submitted two different drafts of the updated SGEIS and had received an unprecedented number of critical comments from stakeholders and the public. Given the sizeable public opposition, the process had stalled and the NY Department of Health was called in to do an independent review of the risk to public health.

The debate was convened by the Cornell University Speech and Debate Society during the fifth year of the conflict while the Department of Health was doing an independent review. While the debate was held on the Cornell campus the majority of the audience was not of traditional student age. The debate brought together six experts to address the proposition, "Should We Lift the Ban?" The proponents for lifting the ban on hydrofracking were: John Conrad, a hydrogeologist who works for PVE Sheffler, LLC, and a member of the public outreach committee of the Independent Oil and Gas Association; Tom Shepstone, Esq., from Shepstone Management and a blogger at Natural Gas Now; 
and Scott Kurkoski, Esq., from Levene, Gouldin and Thompson who represents the Joint Landowners' Coalition of New York. The opponents of lifting the ban were: Sandra Steingraber, an environmental studies and science professor at Ithaca College and member of Concerned Health Professionals of New York; and Walter Hang from the non-profit, Toxics Targeting, and Anthony Ingraffea, a civil and environmental engineer professor at Cornell University who once worked for the gas industry on research and development. For the segments selected for analysis all of the opponents' responses were made by Anthony Ingraffea. I did not intend to focus just on Ingraffea, but his responses used metadiscourse more and were generally more artful.

\section{THE QUESTION-ANSWER PORTION OF THE DEBATE}

The debate lasted nearly one and a half hours. This study will focus on the audience's questions and the debaters' responses. Before turning to the $\mathrm{Q}$ and $\mathrm{A}$ segment, the opening rounds of the debate are summarized. After the participants introduced themselves, the moderator explained the ground rules and posed three questions and moderated the replies and rebuttals. Each side gave their position and then responded to each other. The first question was on the effects of hydrofracking on the local environment and human health. Those for lifting the ban argued that natural gas emitted half the green-house gases as coal, would serve as a bridge fuel to alternative energy sources, and health wise saves lives and visits to the doctor. Opponents contended that fracking merely relocated air pollution from cities to rural areas leading to an increase in asthma among children. In addition, fracking would slow down the transition to alternative energy. The second question was on the economic consequences of hydrofracking. Proponents claimed that hydrofracking lowered energy costs, created jobs, and that income rose by $19 \%$ in counties in Pennsylvania with hydrofracking. Opponents contended that fracking creates a boom and bust economy, mostly benefits out-of-state workers, and reduces local property values. The third question dealt with the impact on climate change. Those opposed to fracking pointed out that methane released from hydrofracking was much higher than previously thought and methane emissions are much more damaging to the climate. Proponents claimed that methane loss was only $1-2 \%$ and in any event fracking was much better than coal for the climate. The debaters cited a number of authoritative sources to support their claims: the Intergovernmental Panel on Climate Change, the Department of Energy, the National Oceanic and Atmospheric Association, the Environmental Protection Agency, the NY Department of Environmental Conservation, the Independent Oil and Gas Association as well as a number of peer-reviewed research studies.

\section{Hydrofracking and Water Contamination}

Turning to the Q and A segment, in the following excerpt an audience member asks what are we to do given the conflicting scientific findings and assessments on hydrofracking. A profracking debater replies by blaming the other side which in turn is rebutted an anti-fracking advocate.

\#1 (52:35: AM1 is audience member one; SN is the moderator, Sam Nelson, TS is Tom Shepstone, pro-fracking debater; Aud is the audience; AI is Anthony Ingraffea, anti-fracking debater).

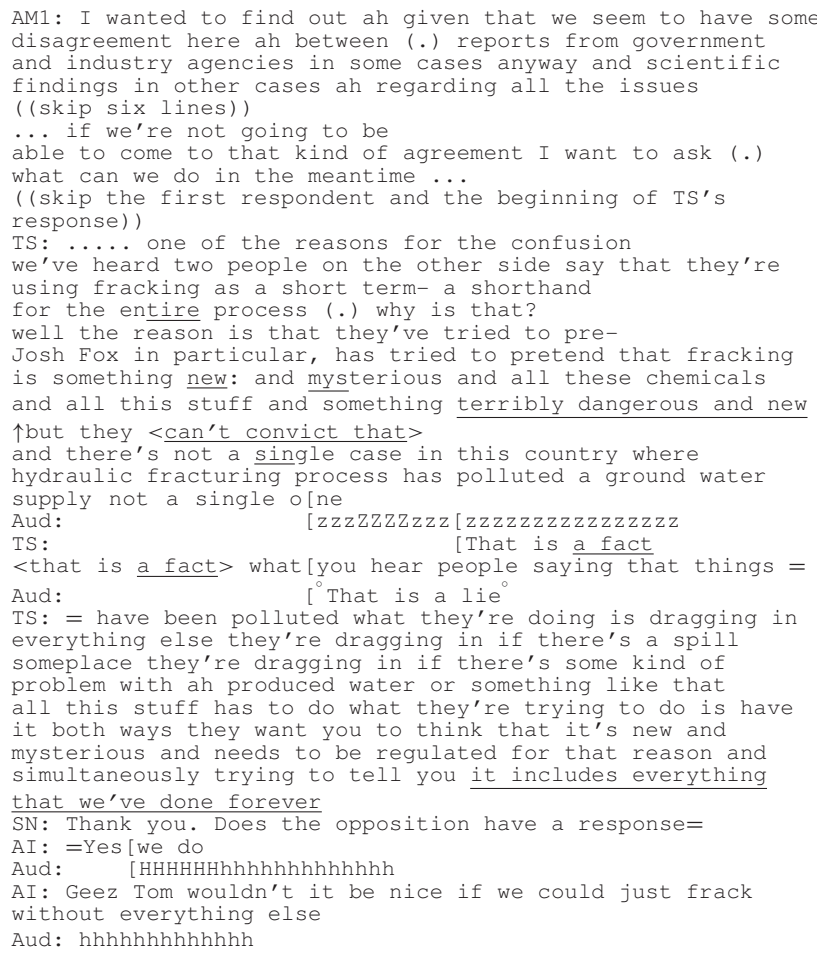

To give a quick overview of what is happening here the disagreement is over the meaning of hydrofracking-does it involve just the literal fracturing of the shale or the entire process of gas extraction. The focus of this investigation is to examine how these accounts are put together, how these differing positions are discursively constructed and responded to. That is, to describe the discursive practices participants use in building their case or contesting opponents.

At times participants refer to their own or others' talk. This reflexive practice of talking about talk has been called "metadiscourse" (Craig, 2005). Metadiscourse is an interesting practice in that it allows us to see how participants characterize or evaluate their own or others' talk. Metadiscourse works to notice or comment on some feature of the interaction-as good or bad, problematic, ironic, and so forth. This noticing or assessment of talk functions as a form of accountingas criticizing, blaming, justifying, or explaining the event in question.

The first instance of metadiscourse is the audience member's formulation of the upshot of the debate as "some disagreement...between ...reports from government and industry... and scientific findings". A formulation is a shorthand metadiscursive summarizing of what has been said, a way of identifying the "gist" or "upshot" of a discussion (Heritage and Watson, 1979). This formulation comes prior to his query, what can we do? Of all the audience questions that were raised, this one seems the least partisan. 
Pro-fracking advocate, Tom Shepstone, responds by reformulating AM1's formulation, "some disagreement," as instead, "confusion". Having reformulated the opposing side as confused, Shepstone proceeds to clarify this "confusion" by accounting for how it came about.

Shepstone's account contrasts what others have said to what is really the case. To draw this contrast he uses another form of metadiscourse, "reported speech," to summarize what the opposing side said, and "reported action" to describe what antifracking partisans have done. Reported speech is the discursive practice of drawing on the words of others to either support the reporting speaker's position or to criticize others. There are various kinds of reported speech, such as direct speech and indirect speech. Direct speech purportedly quotes or captures the exact words of what another said, while indirect speech conveys the propositional content of what was said but not the exact words. Shepstone's account here begins with indirect speech, "we've heard two people on the other side say that they're using fracking as a short term- a shorthand for the entire process." Notice the vocalic emphasis on "entire," as in "the entire process," for that is the crux of the disagreement. He adopts the gas industry position that hydrofracking refers to just the actual fracturing of the shale, not the surrounding industrial processes associated with it (also, see Dodge, 2017, p. 902). So in reporting the speech of the "two people on the other side," Shepstone is implicitly criticizing them for that promiscuous usage. A moment later, he uses indirect speech again, "what you hear people saying that things have been polluted". Here these words are attributed broadly, not to any one individual, but to what "people" are saying. In both these instances of reported speech, Shepstone is criticizing what others have said.

A related practice to reported speech is reported action. Instead of reporting what another said, reported action conveys what they did, their actions. For instance, Shepstone describes the actions of Josh Fox, the film maker of Gasland, an antifracking documentary (Fox, 2010). "Josh Fox in particular, has tried to pretend that fracking is something new: and mysterious...". A moment later, Shepstone expands on his indirect speech of "what you hear people saying" by reporting their actions: "what they're doing is dragging in everything else they're dragging in if there's a spill someplace they're dragging in if there's some kind of problem with ah produced water...". Obviously he is being critical of these actions as reflected in his descriptions and word choice, i.e., Josh Fox is pretending, and people are dragging in everything. In addition to word choice, the prosodic emphasis on "new: and mysterious" and "terribly dangerous and new" underscores the fraudulent moves Josh Fox is making. In describing "what you hear people saying," Shepstone's locution, "they're dragging in...," used three times in succession constructs a list of their inaccurate assertions.

In constructing his account, Shepstone contrasts the reported speech of the "two people on the other side" and that of "Josh Fox" with what really is the truth about hydraulic fracturingthat it has never polluted any ground water. He emphasizes this record of never polluting by adding, "not a single one", which provokes some "response cries" (Goffman, 1981) from the audience. Response cries are an immediate vocal or verbal reaction to another's words or deeds. In these response cries, no words are discernable, but we hear audience noises-gasps, grumblings, inaudible heckling. Response cries are transcribed with upper-case or lower-case z's to indicate their loudness. Shepstone responds immediately to the audience rumblings by speaking over them and asserting "that is a fact", and then repeating it more emphatically by saying it slowly and with vocalic emphasis " $<$ that is a fact $>$ ". As he proceeds with his critique of the anti-fracking view, an audience member says overlapping Shepstone, "That is a lie ". So we have Shepstone's assertion "that is a fact <that is a fact $>$ " and then an audience member's heckling " That is a lie ". Each of these assertions, "that is a fact" and "that is a lie," are metadiscursive. Speaking into the microphone Shepstone apparently does not notice or respond to this audience heckling; he precedes into his critical account with the reported speech "What you hearing people saying..." (discussed above).

Based on audience questions, applause, laughter, heckling, and response cries, most of the audience appears to favor the anti-fracking position. In terms of risk construction we see Shepstone's account attempting to mitigate the perception of risk by undermining the anti-fracking side's use of hydrofracking and the spurious claims associated with it. Clearly his accounting blames the opposing side for their misleading characterization of hydrofracking.

Upon competition of Shepstone's critical account, the moderator asks the anti-fracking side if they have a response and he gets an immediate reply from Ingraffea, "Yes we do," which begets a knowing laughter from the audience. Ingraffea smiles as he responds which may cue in the audience's knowing laughter. Ingraffea's mocking rebuttal, "Geez Tom wouldn't it be nice if we could just frack without everything else" engenders further audience laughter. In this rebuttal he draws on Shepstone's own words "everything else," from a prior reported action, "what they're doing is dragging in everything else". Such a reply in reporting Shepstone's speech, "everything else," is quite artful in turning his own words upon himself. In Ingraffea's rebuttal, less is more.

In ongoing environmental conflicts it seems there are persistent issues or points of contestation that opposing sides offer different arguments for or against. Here we have seen the gas industry's talking point on what constitutes hydraulic fracturing and opponents' criticism of that view. Next we will examine another point of contention that the anti-fracking side champions in their criticism of the gas industry, the so-called Halliburton loophole.

\section{Halliburton Loophole}

The Halliburton loophole is commonly understood as a provision in the 2005 Energy bill negotiated by the Bush/Cheney administration which exempts the gas and oil industry from regulations of the Clean Water Drinking Act. Our interest here is in how the debate participants understand the Halliburton 
loophole, discursively construct it, and use it rhetorically. Mention of the Halliburton loophole arises in response to an audience member question.

\#2 (58:27: JC is John Conrad, pro-fracking geologist).

AM2: Why is it that the oil and gas industry needs to have exemptions at the federal level, environmental exemptions .. why? (.) why all this special treatment? so that this

SN: Thank you I think we understand the question

TS: I'll answer it very quickly and if John wants to add

something, first of all the industry is not exempt from the

Clean Water Act they require permits all the time

Clean water Act they require permits all the time

if you want a good explanation of how it works I would

Tony Ingraffea from () in 2010 where he says there is no

Halliburton loophole and he explains it I think very fairly

as to how this comes about the- and there's numerous

permits required under the Clean Water Act for what the

industry does so it's a misnomer to say there's an

exemption ..

((skip fourteen lines))

SN: Thank you, a response?

AI: Yes Tom I glad to hear that you're listening to some of

my talks but what I was trying to explain to the public

back then the reason why the Haliburton loophole isn't a

lack then the reason why the Haliburton loophole isn't a

loophole is that it was always there (1.2) it was just a

confirmation with the word explicitly included in the

Water, Clean

Air (.) Safe Water Drinking Act it's literally there it's

in federal law all that law did was to confirm what was the

general understanding between the oil and gas industry and

the federal government so it is a fact, it remains a fact

that oil and gas industry is the only industry in the

United States that is by federal law exempt (.) from

federal regulation according to the safe Drinking Water,

Clean Water and Clean Air Act, it's a fact

The audience member's question is clearly critical of the oil and gas industry in citing their "environmental exemptions" and "special treatment." The environmental exemptions of the Halliburton loophole are a cause celebre among hydrofracking critics. The reason being if hydrofracking is so safe, why does it need exemptions from environmental regulations?

Shepstone immediately replies by denying that the industry gets any special exemptions. He further denies that there is a Halliburton loophole. Shepstone qua attorney displays expertise in hearing the word "exemptions" as implicating the Halliburton loophole and the Clean Water Act. He further invokes a video of Tony Ingraffea to support his position. He uses indirect speech from Ingraffea's video to say "there is no Halliburton loophole" and uses metadiscourse to formulate Ingraffea's explanation as very fair. Given that Ingraffea is a leader on the anti-fracking side, being able to use Ingraffea's testimony to undermine the Halliburton loophole critique would be a major debate point.

In response Ingraffea directly addresses Shepstone to rebut his claim. But instead of the short pithy reply of excerpt 1 , here Ingraffea delivers an elaborated detailed response. He uses indirect speech to summarize what he said on the video and to correct Shepstone's understanding, "the Haliburton loophole isn't a loophole (because) it was always there". Given that Ingraffea is talking about his own talk gives him a privileged epistemic position. Indeed Ingraffea displays expertise in explaining the law and its background.

Ingraffea uses metadiscourse to underscore the Halliburton loophole exemptions as "a fact". This raises the epistemic question of what do the opposing sides disagree about, are they disagreeing over matters of fact or something else. As regards excerpt 1 the question turns on how narrowly hydraulic fracturing is to be defined. In excerpt 2 Ingraffea may score a debate point against Shepstone, but he avoids addressing the proposed New York State regulations on hydrofracking.

\section{The Feasibility of Shifting to Non-fossil Fuel Energy}

Natural gas is often cited as a transition or a bridge fuel to alternative energy sources. Opponents contend that allowing hydrofracking will slow down the move to non-fossil fuels. These competing accounts are evident in the following exchanges.

Returning to Ingraffea's response from excerpt \#1, he turns from his rebuttal of Shepstone to answer the original question. Basically Ingraffea proposes a plan of shifting to non-fossil fuel energy by 2030. The focus here is on how the plan is discursively constructed and received in the course of the debate.

\#3 (AI is Anthony Ingraffea, anti-fracking debater).

((Continuation of excerpt \#1))

AI: but I just want to answer the question that was asked if not shale gas then what, and

I promised you that I'd only refer to peer-reviewed science and I was lucky enough to be a co-author on a paper that appeared since the last debate that answered that question <for New: York: :

we published a paper in Energy Policy about eight months ago that said given todays' technology and given today's pricing structure for wind water and solar it is perfectly feasible technically and economically to convert all of New York's energy uses transportation heating and electricity generation to non-fossil fuels sources by 2030

generation to non-fossil fuels sources by 2030
we lack on:ly (.) legislative regulatory and governmental will power to do so $\uparrow$ and since this is a democracy (.)

and you control all those things (.) do it

AUD: XXXXXXXXXXXXXXXXXXXXXXXXXXXXXXXXXX

Here Ingraffea pivots from rebuttal (excerpt 1) to addressing the original question from the audience member. He shifts footing by using metadiscourse to announce what he is going to address, "to answer the question that was asked". This metadiscourse serves here as a discourse marker to signal his transition from rebuttal to his own position. He then formulates the audience member's question (from excerpt 1) via indirect reported speech, "if not shale gas then what".

But as a preliminary to addressing this question, Ingraffea displays expertise by aligning himself with the authority of science. He uses indirect speech to remind the audience of what he said earlier in the debate about only referring to "peerreviewed science". Then he cites the paper he co-authored and the journal. He addresses the question via indirect discourse to report the findings from the paper: it is technically and economically possible to convert all of New York's energy needs into non-fossil fuels by the year 2030. He shifts footing again from reporting from his paper to advocating for the audience to "do it."

Later in the debate a question is raised by an audience member that allows the pro-fracking side to address Ingraffea's 2030 plan for alternative energy. Most of the audience members' questions and responses have favored the anti-fracking side; this is the only one favoring the pro-fracking position.

\#4 (AM3 is audience member 3 )

AM3: ((reading)) Given that high capital costs for current alternative energy makes it unattainable for many rural communities why should we discourage the transition to less harmful natural gas instead of being forced into a dichotomy of staying with heavy polluting coal generators or switching to expensive alternative energy putting major economic pressure on low income families

Aud: XXXXXXXXX

To summarize the audience member's question, given the high costs of alternative energy, shouldn't more affordable and cleaner natural gas be allowed? An anti-fracking debater answers first challenging the premise of the question. I omit that and move on to the pro-fracking side's response. 


\section{\#5 (1:06: JC is John Conrad, pro-fracking)}

JC: Well I think it's a great question and ah I think part of the answer is that by definition we are talking about a transition nobody is thinking that we are going to flip a switch tomorrow and convert our economy to something that doesn't use any fossil fuels so we are talking about a period of decades, maybe a couple of generations before you could switch over to a very low or zero carbon energy future. Tony mentioned that by 2030 that under some idealized scenario you might- you would be able to stop using fossil fuels ah: $\uparrow$ but 2030 is still 16 years away a(h) nd so again even under the most ideal scenario you're a(h) nd so again even under the most ideal scenario you're talking about a couple of decades before we could switch ronewables

Conrad begins by formulating the audience member's question as "a great question" in marked contrast to the anti-fracking debater challenging the question's premise. Conrad metadiscursively uses the audience member's term "transition" into "we are talking about a transition". Conrad's locution, "we are talking about," is an interesting bit of metadiscourse to indicate what they have been advocating for, what he formulates as "a transition." A moment later he repeats this locution speculating on the length of the transition, "so we are talking about a period of decades, maybe a couple of generations...". And again, "you're talking about a couple of decades". The implied point being that natural gas is needed during this lengthy period of transition. The argument for natural gas as a transition allows Conrad to agree on the need for non-fossil fuel energy, but also implicates for the necessity of hydrofracking during this transition.

Conrad then moves to rebut Ingraffea's 2030 plan as unrealistic. He formulates Ingraffea's plan by indirect speech, "Tony mentioned that by 2030 that under some idealized scenario you might- you would be able to stop using fossil fuels." By formulating it as "some idealized scenario," Conrad implicates the plan's problematic character. And he adds "2030 is still 16 years away" followed a brief laugh particle embedded in "a(h)nd" to underscore how unrealistic the plan is since energy is needed in the interim. He concludes by repeating and upgrading his criticism "even under the most ideal scenario you're talking about a couple of decades".

The moderator then turns to let Ingraffea respond. Ingraffea responds to both the audience member's question (excerpt \#4) and to Conrad's criticism (excerpt \#5).

\#6 (1:09 AI is Anthony Ingraffea)

AI: I appreciate the question also but I also don't think your premise of the higher cost of renewables is correct I'm quoting from a peer-reviewed publication

( (reading)) win:d is currently the cheapest source of

((reading)) win:d is currently the cheapest

electric
$(2.1)$

excuse me wind is currently the cheapest form of electric

power in the United States today ...

( (skip 3 lines))

so you also mentioned a rural community last I looked

Ithaca was a rural community (.)

we have a community scale wind farm under construction (.) we have Solarize Tompkins county

we'll have thousands of homes in Tompkins County with solar panels on their roofs in the next few years

and I agree nothing is going to happen overnight but

we can't wait until 2030 to start (1.0) thank you

AUD: $x$ x $x$ x $x$ x

AI does not immediately address JC's prior critique, but begins by responding to the audience member's question by challenging the premise of the question. AI uses direct reported speech to formulate AM3's premise, "the higher cost of renewables". But the premise of AM3's question is actually somewhat different, "high capital costs for current alternative energy" (excerpt \#3). That is, "high capital costs" get slightly altered by Ingraffea to "the higher cost of renewables." Again we see the strategic importance of formulating what has been said as a prelude to addressing it, in this case to challenging it.

Ingraffea supports his challenge by drawing on a science-based source. Again Ingraffea uses metadiscourse to cite his source by reading from, as he puts it, "a peer-reviewed publication." Previously Ingraffea displayed expertise by summarizing his own paper (excerpt \#3), here he reads a sentence from a scientific publication. Upon competition he pauses for dramatic effect and looks to the audience before repeating his assertion on the low cost of wind energy.

Ingraffea continues by again using direct speech from AM3's question, "you also mentioned a rural community". He then identifies Ithaca as a "rural community" and proceeds to list the wind and solar projects underway in Ithaca. But it is unlikely that AM3 had Ithaca in mind when she mentioned rural communities. The greater Ithaca area may be rural, but Ithaca itself, a college-town, is one of the most prosperous upstate communities. In any event, Ingraffea employs a listing of the alternative energy projects introduced by a variation of the locution "we have X". This repeating "we have $\mathrm{X}$ " is formed into a three-part list which gives a sense of a generalization or completeness to his claim.

Ingraffea continues by shifting footings and responding to Conrad's critique. He concedes that "nothing is going to happen overnight," his formulation of Conrad's metaphor "flip a switch tomorrow and convert our economy" (excerpt 4). Ingraffea then sums up the gist of his account with "but we can't wait until 2030 to start" which receives s scattering of audience applause. Ingraffea eludes addressing the transition argument and the necessity for natural gas in the interim.

So we see that metadiscourse provides a ready resource for debaters to draw on or summarize another's words or position, or to formulate what another said or did. Having characterized other's views one can then critique it or contrast it with one's own position.

\section{DISCUSSION}

This debate saw experts offer conflicting testimony on the risks of permitting hydrofracking in New York State. This state-of-affairs of experts disagreeing on technological controversies is not uncommon. The focus of this paper was on how debaters displayed expertise in and through their discourse and interactive moves. As mentioned above, a debate makes for a kind of performative contest among experts. "Expertise is inherently interactional... and always ideological" (Carr, 2010, p. 18). For instance, Ingraffea displayed expertise through his "scientized" (Sarewitz, 2004) knowledge in metadiscursively referencing peer-reviewed papers or his own journal article. Shepstone displayed expertise by anticipating issues implicated by the audience member's question about the industry receiving "special treatment" as did Conrad by his critique of the 2030 plan. These experts were also advocates. They spoke beyond their area of expertise, e.g., Conrad's 
criticism of the 2030 plan was not about geology; Ingraffea, an engineer, discussed the Halliburton loophole in federal law. Ingraffea, in particular, stood out as having the most adept performance in the debate, e.g., he corrected Shepstone on the Halliburton loophole, humorously mocked Shepstone's narrow characterization of fracking, and a few times used repetition skillfully to implore the audience to action which received applause.

The main contribution from this study comes in showing how risk gets socially constructed through participants' interactive discourse. Risk gets articulated, in part, through discursive practices of metadiscourse-talk about talk. This reflexive practice allows participants to characterize or evaluate their own or others' claims as true or false, right or wrong, or risky or not. Two main kinds of metadiscourse examined here were formulations and reported speech. Participants formulated the state of their opponents' position or an audience member's question into their preferred version prior to responding to it. Another type of metadiscourse is reported speech or reported action (direct or indirect discourse). Reported speech allows one to use another's or one's own prior words for one's own purposes such as to criticize another or support one's position. Reported speech/action involves more than just reporting; these practices allow one to critically evaluate what was said or done. These metadiscourse practices constitute some of the ways risk gets discursively constructed.

Turning to the risk communication literature, these metadiscursive practices of formulations or reported speech/action add to our understanding of "the symbolic processes of representation" (Boholm, 2009). These metadiscursive practices do more than representation; they are also speech actions designed to criticize or bolster a position. The use of reported speech/action fits Mary Douglas' (1992) observation that to attribute risk is to blame. Discursive constructionism allows us to move beyond the social amplification of risk approach based on a transmission model of communication (Pidgeon et al., 2006; Boholm and Corvellec, 2014). Participants do attempt to amplify (attenuate or magnify) risk, but they do so interactively, in part, through these practices of metadiscourse.

In the hydrofracking literature Dodge's (2017) study of the controversy in New York State showed how competing discourse coalitions' framing strategies evolved in responding to each other. "Advocates... produced knowledge and rigorously debated others' knowledge claims, at times holding scientists and other knowledge producers accountable for reliable information" (Dodge, 2017, p. 909, emphasis added). The findings from the present study extend our understanding of how opponents can be held accountable. For instance, Ingraffea uses metadiscourse to hold Shepstone accountable for his narrow characterization of fracking, and later accountable to the existence of the Halliburton loophole in federal law; Conrad uses reported speech in holding Ingraffea accountable for the holes in his 2030 plan. Different forms of metadiscourse are used in holding an opponent accountable for their problematic statements. In their review of the literature, Matthews and Hansen state that "Assessment of the relative success of the pro-fracking and anti-fracking discourses are relatively rare in the academic literature" (Matthews and Hansen, 2018, p. 5). But the above mentioned discursive practices of holding opponents' accountable show some practices of assessing fracking discourse.

The question arises whether using metadiscourse allows a speaker to be more effective in public presentations. The metadiscursive practice of formulating what another said functions to allow the speaker to define or characterize an issue in one's preferred terms prior to addressing it. Also, reported speech allows speakers to be more specific in their account, to show rather than tell what happened which is more involving for an audience. But of course no practice is fool proof, as we saw Shepstone in excerpt \#1 use a reformation and reported speech and reported action only to be soundly rebutted by Ingraffea.

The audience played an important part in this debate, not only with their questions, but also by their responsesapplause, laughter, heckling, and grumblings. These audience responses are metadiscursive in that they assess a debater's statements. At times the debater addresses the audience's responses as was seen when Shepstone defended his claim (excerpt \#1) or Ingraffea was bolstered by audience applause.

The debate allows for audience deliberation in that partisans' claims get tested through challenges or opposing accounts (Gelfert, 2011). Long held points of contention (e.g., ground water contamination; the Halliburton loophole) became scrutinized. Looking at the debate from a critical perspective, certain key questions were also avoided. For example, Ingraffea may have scored a debate point on the Halliburton loophole, but he avoided acknowledging state-level regulations. Also, Ingraffea elided addressing the need for energy during the transition to alternatives. The performative demands of a debate help to bring together conflicting views but they also do not allow for a thorough investigation of differences.

Nonetheless, debate remains a valuable format for discussing environmental controversies. Even though the audience is left with competing expert testimony, the public can garner evidence or testimony to add to their understanding of the issues. At the end of the day, values may be the ultimate basis for a decision on the hydrofracking controversy, but the reasons, testimony, and evidence from debate can be used to support that decision.

\section{ETHICS STATEMENT}

This study involved public figures in a debate before an audience.

\section{AUTHOR CONTRIBUTIONS}

The author confirms being the sole contributor of this work and has approved it for publication. 


\section{REFERENCES}

Auyero, J., Hernandez, M., and Stitt, M. E. (2017). Grassroots activism in the belly of the beast: a relational account of the campaign against urban fracking in Texas. Soc. Prob. 66, 28-50. doi: 10.1093/socpro/spx035

Beck, U. (1992). Risk Society. London: Sage Publication.

Boholm, Å. (2009). Speaking of risk: matters of context. Environ. Commun. 3, 335-354. doi: 10.1080/17524030903230132

Boholm, A., and Corvellec, H. (2014). A relational theory of risk. J. Risk Res. 14, 175-190. doi: 10.1080/13669877.2010.515313

Boudet, H., Clarke, C., Bugden, D., Maibach, E., Roser-Renouf, C., and Leiserowitz, A. (2014). "Fracking" controversy and communication: using national survey data to understand public perceptions of hydraulic fracturing. Energy Policy 65, 57-67. doi: 10.1016/j.enpol.2013.10.017

Briggle, A. (2015). A Field Philosopher's Guide to Fracking: How One Texas Town Stood up to Big Oil and Gas. New York, NY: Liveright Publishing.

Buttny, R. (2004). Talking Problems: Studies of Discursive Construction. Albany, NY: State University of New York Press.

Buttny, R. (2015). Contesting hydrofracking during an inter-governmental hearing: accounting by reworking or challenging the question. Discourse Commun. 9, 423-440. doi: 10.1177/1750481315576842

Buttny, R. (2017). Accounting for "How We Know" about the safety/risks with hydrofracking: an inter-governmental hearing on the revised environmental impact statement on whether to permit hydrofracking in New York State. J. Risk Res. 1-12. doi: 10.1080/13669877.2017.1378251

Carr, E. S. (2010). Enactment of expertise. Annu. Rev. Anthropol. 39, 17-32. doi: 10.1146/annurev.anthro.012809.104948

Chen, S., and Gunster, S. (2016). "Ethereal carson": legitimizing liquefied natural gas in British Columbia. Environ. Commun. 10, 305-321. doi: 10.1080/17524032.2015.1133435

Christenson, D. P., Goldfarb, J. L., and Kriner, D. L. (2017). Cost, benefits, and the malleability of public support for "fracking." Energy Policy 105, 407-417. doi: 10.1016/j.enpol.2017.03.002

Cornell Forensics Club (2014). Fracking II: Should we Lift the Ban. Available online at: https://www.youtube.com/watch?v=IHMQQIh8hto

Craig, R. T. (2005). How we talk about how we talk: communication theory in the public interest. J. Commun. 55, 659-667. doi: 10.1111/j.1460-2466.2005.tb03015.x

Dodge, J. (2017). Crowded advocacy: framing dynamics in the fracking controversy in New York. Voluntas 28, 888-915. doi: 10.1007/s11266-016-9800-6

Dokshin, F. A. (2017). Whose backyard and what's at issue? Spatial and ideological dynamics of local opposition to fracking in New York state, 2010-2013. Am. Sociol. Rev. 72, 408-446. doi: 10.1177/0003122416663929

Douglas, M. (1992). Risk and Blame. New York, NY: Routledge.

Duggan-Hass, D., Ross, R. M., and Allom, W. D. (2013). The Science Beneath the Surface: A Very Short Guide of the Marcellus Shale. Ithaca, NY: Paleontological Research Institution.

Fisher, F. (2000). Citizens, Experts, and the Environment. Durham, NC: Duke University Press. doi: 10.1215/9780822380283

Fox, J. (2010). Gaslands: A Documentary Film. HBO.

Gelfert, A. (2011). Expertise, argumentation, and the end of inquiry. Argumentation 25, 297-312. doi: 10.1007/s10503-011-9218-7

Goffman, E. (1981). "Response cries," in Forms of talk (Philadelphia, PA: University of Pennsylvania Press), 78-123.

Guignard, J. (2013). "A certain uncertainty: Drilling into the rhetoric of Marcellus Shale natural gas development," in Environmental Rhetoric and Ecologies of Place, ed P. N. Goggin (New York, NY: Routledge), 15-27.

Gullion, J. S. (2015). Fracking the Neighborhood: Reluctant Activists and Natural Gas Drilling. Cambridge, MA: MIT Press. doi: 10.7551/mitpress/9780262029766.001.0001

Hepburn, A., and Bolden, G. B. (2017). Transcribing for Social Research. New York, NY: Sage Pub. doi: 10.4135/9781473920460

Heritage, J., and Watson, D. R. (1979). "Formulations as conversational objects," in Everyday Language: Studies in Ethnomethodology, ed G. Psathas (New York, NY: Irvington), 123-162.

Hilgartner, S. (2000). Science on Stage: Expert Advice as Public Drama. Stanford, CA: Stanford University Press.

Kiernan, P. J. (2012). An analysis of hydrofracturing gubernatorial decision. Albany Govern. Law Rev. 769, 769-809. Available online at: https://heinonline.org/HOL/Page?handle=hein.journals/aglr5\&div=35\&g_sent
=1\&casa_token=13p3nq4XEJQAAAAA:_hFUNtyuYAVtACfWmyeKysWyOO zMuHT6xBGeCyq0V3CDy_xL9AWwSilvH8Njxd2RRnhqBAH2\&collection= journals

Krimsky, S., and Plough, A. (1988). Environmental Hazards: Communicating Risks as a Social Process. Dover, MA: Auburn House.

Kroepsch, A. (2016). New rig on the block: spatial policy discourse and the new suburban geography of energy production on Colorado's front range. Environ. Commun. 10, 337-351. doi: 10.1080/17524032.2015.1127852

Llewellyn, N. (2005). Audience participation in political discourse: a study of public meetings. Sociology 39, 697-716. doi: 10.1177/0038038505056028

Lupton, D. (2013). Risk, 2nd Edn. New York, NY: Routledge.

Mando, J. (2016). Constructing the vicarious experience of proximity in a Marcellus Shale public hearing. Environ. Commun. 10, 352-364. doi: 10.1080/17524032.2015.1133438

Matoesian, G. (1999). The grammaticalization of participant roles in the constitution of expert identity. Lang. Soc. 28, 491-521. doi: $10.1017 /$ S0047404599004017

Matthews, J., and Hansen, A. (2018). Fracturing debate? A review of research on media coverage of "fracking." Front. Commun. 3, 1-11. doi: $10.3389 /$ fcomm.2018.00041

Mazur, A. (2016). How did the fracking controversy emerge in the period 20102012? Public Understand. Sci. 25, 207-222. doi: 10.1177/0963662514545311

Metze, T. (2014). Fracking the debate: Frame shifts and boundary work in Dutch decision making in shale gas. J. Environ. Policy Plan. 19, 35-52. doi: 10.1080/1523908X.2014.941462

Metze, T., and Dodge, J. (2016). Discourse coalitions on hydro-fracking in Europe and the United States. Environ. Commun. 10, 365-379. doi: $10.1080 / 17524032.2015 .1133437$

Myers, G. (2007). Commonplaces in risk talk: face threats and forms of interaction. J. Risk Res. 10, 285-305. doi: 10.1080/13669870601070536

Palmlund, I. (1992). "Social drama and risk evaluation," in Social Theories of Risk, eds S. Krimsky, and O. Golding (New York, NY: Praeger).

Perry, S. L. (2012). Addressing the societal costs of uncovential oil and gas exploration and production: a framework for evaluating short-term, future, and cumulative risk and uncertainties of hydrofracking. Environ. Pract. 14, 352-365. doi: 10.1017/S1466046612000336

Pidgeon, N., Simmons, P., and Henwood, K. (2006). "Risk, environment, and technology," in Risk in Social Science, eds P. Taylor-Gooby and J. O. Zinn (Oxford: Oxford University Press), 94-116.

Pidgeon, N., Thomas, M., Partridge, T., Evensen, D., and Harthorn, B. H. (2017). "Hydraulic fracturing: a risk for environment, energy security, and affordability?” in Risk Conundrums, ed R.E. Kasperson (New York, NY: Routledge), 177-188.

Renn, O. (1992). "The social arena concept of risk debates," in Social Theories of Risk, eds S. Krimsky and D. Goldberg (New York, NY: Praeger), 179-194.

Rich, J. L. (2016). Drilling is just the beginning: romaniticizing rust belt identities in the campaign for shale gas. Environ. Commun. 10, 292-304. doi: $10.1080 / 17524032.2016 .1149085$

Sarewitz, D. (2004). How science makes environmental controversies worse. Environ. Sci. Policy 7, 385-403. doi: 10.1016/j.envsci.2004.06.001

Tracy, K. (2003). "Introduction: a moment of ordinary democracy," in The Prettier Doll: Rhetoric, Discourse and Ordinary Democracy, eds K. Tracy, J. McDaniel, and B. E. Gronbeck (Tuscaloosa, AL: University of Alabama Press), 3-21.

Vasi, I. B., Walker, E. T., Johnson, J. S., and Tan, H. F. (2015). "No Fracking Way!” Documentarys film, discursive opportunity, and local opposition against hydraulic fracturing in the United States, 2010-2013. Am. Sociol. Rev. 80, 934-959. doi: 10.1177/0003122415598534

Wilber, T. (2015). Under the Surface: Fracking, Fortunes, and the Fate of the Marcellus Shale (Updated Version). Ithaca, NY: Cornell University Press.

Conflict of Interest Statement: The author declares that the research was conducted in the absence of any commercial or financial relationships that could be construed as a potential conflict of interest.

Copyright (๑) 2019 Buttny. This is an open-access article distributed under the terms of the Creative Commons Attribution License (CC BY). The use, distribution or reproduction in other forums is permitted, provided the original author(s) and the copyright owner(s) are credited and that the original publication in this journal is cited, in accordance with accepted academic practice. No use, distribution or reproduction is permitted which does not comply with these terms. 


\section{APPENDIX}

[ Marks overlapping utterances.

$=\quad$ Marks when there is no interval between adjacent utterances.

(3.5) Indicates pauses or gaps within or between utterances timed to tenths of a second.

(.) A short untimed pause or gap within or between utterances.

: $\quad$ One or more colons mark the extension of a sound or syllable it follows. The more colons, the longer the sound stretch.

? Marks a rising intonation.

- $\quad$ Marks an halting abrupt cutoff.

$\uparrow \downarrow \quad$ Marks a rising or falling shift in intonation.

word Underlining marks a word or passage said with emphasis.

${ }^{\circ}$ word Degree signs mark a passage that is said more quietly than surrounding talk.

$<$ word $>$ Inverted chevrons marks a passage delivered at a slower pace than surrounding talk.

hhh Audible outbreaths including laughter.

XXX Applause.

() Empty parentheses indicate inability to hear what is said.

((word)) Scenic details or description of the context. 